Discussion Papers
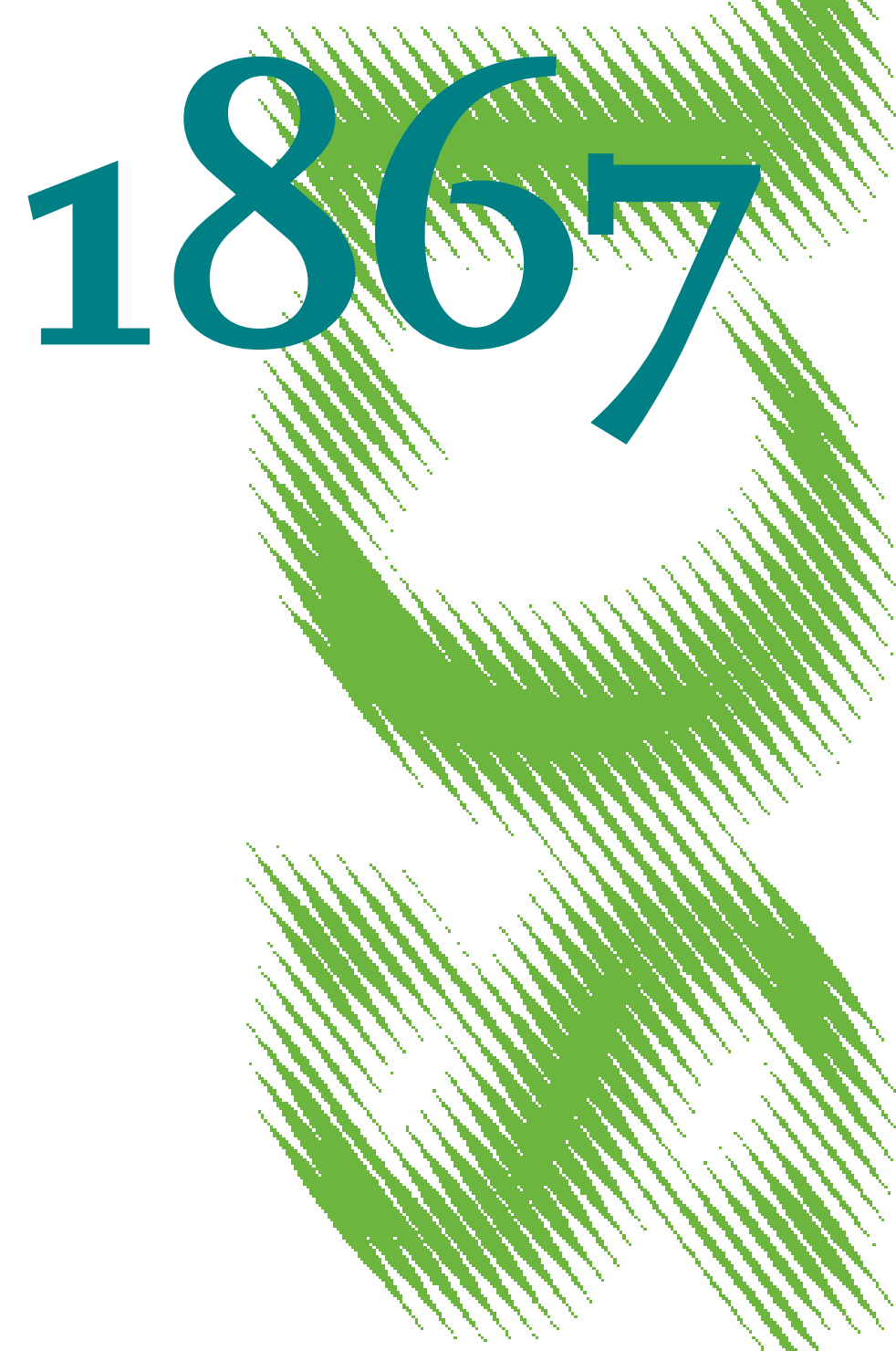

Way Off: The Effect of Minimum Distance Regulation on the Deployment of Wind Power 
Opinions expressed in this paper are those of the author(s) and do not necessarily reflect views of the institute.

IMPRESSUM

(C) DIW Berlin, 2020

DIW Berlin

German Institute for Economic Research

Mohrenstr. 58

10117 Berlin

Tel. +49 (30) $89789-0$

Fax +49 (30) $89789-200$

http://www.diw.de

ISSN electronic edition 1619-4535

Papers can be downloaded free of charge from the DIW Berlin website:

http://www.diw.de/discussionpapers

Discussion Papers of DIW Berlin are indexed in RePEc and SSRN:

http://ideas.repec.org/s/diw/diwwpp.html

http://www.ssrn.com/link/DIW-Berlin-German-Inst-Econ-Res.html 


\title{
Way off: The effect of minimum distance regulation on the deployment of wind power
}

\author{
Jan Stede* and Nils May*
}

Several countries and regions have introduced mandatory minimum distances of wind turbines to nearby residential areas, in order to increase public acceptance of wind power. Germany's largest federal state Bavaria introduced such separation distances of ten times the height of new wind turbines in 2014. Here, we provide a novel monthly district-level dataset of construction permits for wind turbines constructed in Germany between 2010 and 2018. We use this dataset to evaluate the causal effect of introducing the Bavarian minimum distance regulation on the issuance of construction permits for wind turbines. We find that permits decreased by up to 90 percent. This decrease is in the same order of magnitude as the reduction of land area available for wind turbines. The results are in line with findings indicating that minimum distances do not increase the public acceptance of wind power, but harm the expansion of onshore wind power.

Keywords: Onshore wind power, minimum distance, separation distance, energy transition, acceptance, panel data, difference-in-differences, causal inference, event study

JEL codes: C21, Q42, R14, R15

This paper has been updated. The current version is published as DIW Discussion Paper 1989

\footnotetext{
* German Institute for Economic Research (DIW Berlin), Climate Policy Department, Mohrenstr. 58,10117 Berlin, Germany. Email: jstede@diw.de / nmay@diw.de.
} 


\section{Introduction}

Energy transitions worldwide rely on large amounts of electricity from renewable energy sources to reduce emissions (Chu and Majumdar 2012; IPCC 2018). Renewable energies are needed to replace conventional power plants, as well as to power the decarbonisation in other sectors like transport and industry (Bataille et al. 2018; Mitchell 2016). Consequently, the International Energy Agency expects global electricity demand to grow by more than two percent annually until 2040 (IEA 2019).

Wind power is a cornerstone of energy transitions in many countries. Onshore wind power generates electricity at relatively low cost due to technological learning and improvements in financing conditions (Egli et al. 2018), as falling auction bids indicate (IRENA 2019). Global onshore wind power capacity is envisioned to more than double within the next ten years (IEA 2019). In Germany, the share of electricity demand covered by onshore wind has increased steadily in the last two decades (Figure 1). Since the introduction of the German renewables support scheme in 2000, it has risen from less than two percent to more than fifteen percent in 2018. While new installations peaked between 2014 and 2017, newly added capacity has plummeted since. One of the reasons for this decline is that a large number of wind projects cannot be built since the construction permit is being contested in court (Fraunhofer IEE 2019).

Figure 1: Wind power in Germany

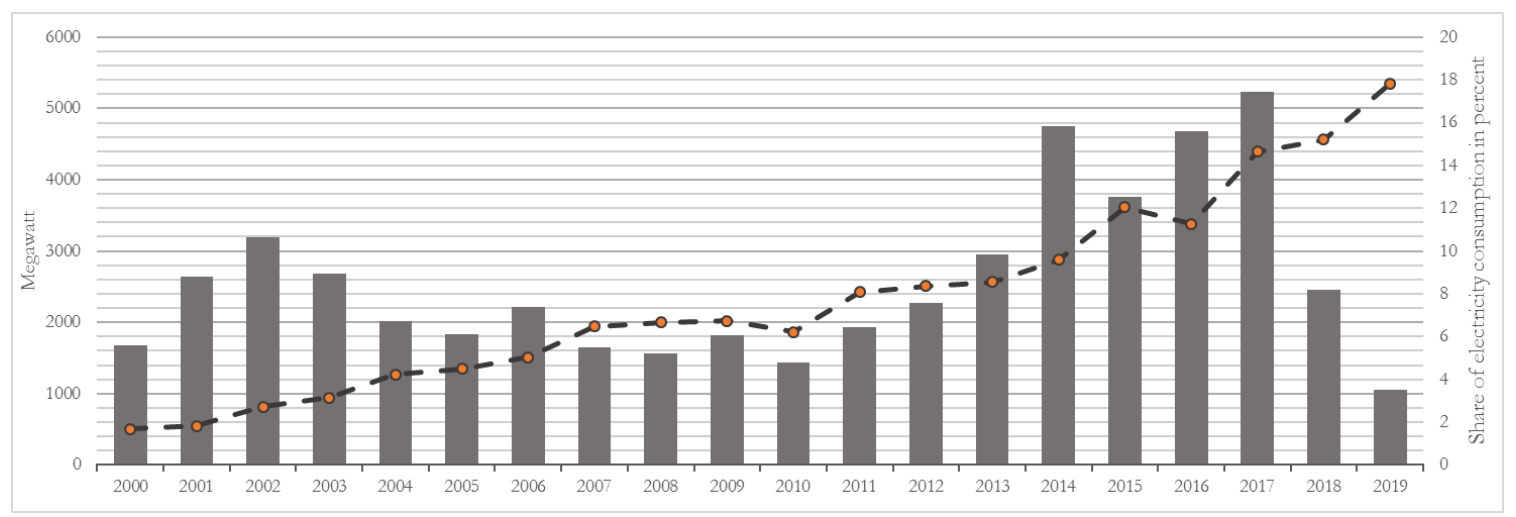

The figure plots the annual onshore wind power additions in Germany (bars, left axis), as well as the respective share of onshore wind power of electricity consumption (dotted line, right axis), based on data from BetreiberDatenbasis (Betreiber-Datenbasis 2019) and the German Federal Ministry for Economic Affairs and Energy (BMWi 2020). Data for 2019 is preliminary.

Although support for renewable energy in general is high, wind energy is more controversial than (small-scale) solar photovoltaics (Cashmore et al. 2019). Onshore wind power requires land and can have negative externalities on local residents (Krekel and Zerrahn 2017). Opposition by residents against new projects may prolong permission processes or prevent installations altogether. Consequently, securing local acceptance of wind turbines is crucial for the deployment of wind power (Wüstenhagen et al. 2007).

Mandatory minimum distances (or separation distances) between wind turbines and residential areas reduce the land area available for new deployment. However, proponents argue that such negative effects on capacity expansion are outweighed because these policies facilitate future growth of wind power by increasing its acceptance (German Federal Government 2019). In recent years, minimum 
distance regulation has become more popular: Scotland, Poland and the German federal state of Bavaria introduced separation distances in 2010, 2016 and 2014, respectively. Moreover, the German Climate Action Programme 2030 includes the intention to introduce such regulation nationally.

While the effects of minimum distance regulation on available land have been assessed before, the actual net effect on new projects is unclear. The lack of suitable data has so far prevented research on this question. The separation distances in Bavaria, for example, directly affect construction permits for wind power plants. On the other hand, the regulation affects new installations of wind turbines (on which data is readily available) only indirectly. However, thus far, there is no comprehensive dataset on building permits for German wind power plants and, as a consequence, no analyses of the direct effect of the Bavarian minimum distance regulation.

We address this gap by evaluating the effect of the minimum distance regulation in Bavaria on the issuance of permits for wind power projects. Wind power plays an essential role in decarbonizing the German energy system, such that the effect of the Bavarian minimum distances has the potential to directly affect the energy transition. Lessons learned from Germany are also relevant for other countries seeking to expand wind power resources.

We assess the Bavarian regulation's effects by creating and analysing a new dataset that comprises information on all permits for German wind turbines that are eventually installed. We combine three distinct datasets and apply statistical inference to identify location, permit date and capacity for all wind turbines installed in Germany between 2010 and 2018. These data can be used to assess the effect of different policies on construction permits for wind turbines in Germany. In this chapter, we evaluate the causal effect of the Bavarian separation distance on the issuance of wind permits.

The results are presented in three steps: First, we introduce our new dataset and information on Bavaria's minimum distance regulation (sections 2 and 3). Second, we identify the causal effect of the regulation on new permits by comparing developments in the federal state of Bavaria to the rest of Germany (section 4). Third, we show how our results relate to federal separation distances, and discuss in how far minimum distance regulation achieves the goal of increasing socio-political acceptance of onshore wind expansion (sections 5 and 6).

\section{Minimum distance regulation in Bavaria}

The federal state Bavaria introduced its minimum distance regulation ("10 H" regulation) to restrict where and what kind of wind turbines could be built. The regulation applies to new building permits for wind turbines. It came into effect in November 2014 (see appendix A.1 for details on the timing of the introduction and its legal treatment). Subsequently, new permits were only granted for installations that have a distance of ten times the height of the wind turbine to residential areas. The height is measured as the sum of the hub height and the rotor blade length. Since the regulation does not differentiate according to visibility (i.e. a turbine on top of a hill is restricted in the same way as a turbine in a valley), this translates into a distance of almost 2,000 meters in practice (see Table 1).

Exemptions exist to the tenfold separation distance in Bavaria. First, local administrations at the municipal level may issue permits without enforcing the regulation when these permits had been filed prior to February 2014. Alternatively, these authorities may introduce exemptions for turbines 
to also be built at lower distances. Consequently, to be able to identify the effect of the Bavarian $10 \mathrm{H}$ regulation on new installations, it is necessary to differentiate between installations that received their permits under application of the new regulation and those that were still issued under the old regulation (see next section).

\section{Data}

\subsection{Creating a new wind permit dataset}

We create a unique district-level dataset containing monthly permits (in megawatt) of wind turbines installed between 2010 and 2018 in Germany. The permit dataset builds on a combination of three different data sources.

First, the backbone of our analyses is the Betreiber-Datenbasis, a private database, in which German wind power plants have been collected since 1988. The Betreiber-Datenbasis contains information on the installation date of German wind turbines and their location, as well as technical parameters like capacity, height and rotor blade lengths. It consists of 10,993 plants constructed between 2010 and 2018, with an average power of 2.7 megawatts (MW). The data quality is very high: Aggregate figures on yearly wind expansion match almost perfectly with the data provided for the German Wind Power Association and the German Engineering Association (Deutsche Windguard 2019).

Second, from the Anlagenregister, a public register of renewable energy installations, we retrieve information on construction permit dates for wind turbines in the Betreiber-Datenbasis. The Anlagenregister is an official publicly accessible database, where all German renewable energy installations between August 2014 and 2019 had to be registered. We merge Anlagenregister and Betreiber-Datenbasis based on an exact match of the variables' month-year of the construction of the wind turbine, their nominal power, as well as their zip code. This results in a dataset with installation data and technical parameters for all wind turbines, and permit dates for a subset of these installations. ${ }^{1}$

Third, not all permits granted after November 2014 were subject to the $10 \mathrm{H}$ rule, since the law introduced some exceptions (section 2). We identify those permits that did comply with the new regulation by using a range of official documents published by the Bavarian Federal Ministry of Economic Affairs as a response to various parliamentary questions by members of the Bavarian parliament. This allows us to estimate the share of permits after November 2014 granted without an application of the minimum distance regulation.

\footnotetext{
${ }^{1}$ For the variable month-year of the construction, we allow for a time lag of up to two months between Betreiber-Datenbasis and Anlagenregister. The reason is that the Betreiber-Datenbasis contains the date when the construction of a wind turbine is completed, whereas the Anlagenregister contains the commissioning date (i.e. when the installation starts producing electricity). Using this approach, we merge around 60 percent of the Anlagenregister's wind turbines with information on the permit date to the Betreiber-Datenbasis.
} 


\subsection{Construction periods of wind turbines}

Despite its official nature, the Anlagenregister does not contain all wind turbines constructed in Germany. In both 2013 and 2014, shortly before the Bavarian separation distances (the $10 \mathrm{H}$ regulation) were implemented, around 40 percent of all installations built in Germany were not registered in the Anlagenregister. Consequently, the wind permit database we create is based on the Betreiber-Datenbasis (which has complete data on all installations), and complemented by information on permit dates from the Anlagenregister.

After merging the two databases Betreiber-Datenbasis and Anlagenregister, we have precise information on the date of construction, but the date that the permits were granted is not available for all plants. For these installations, we approximate the permit date by subtracting typical construction periods from the construction dates. Based on known construction dates, we then derive permit dates for remaining installations by drawing from the distribution of construction times. We do this in several steps.

First, we define the construction time as the commissioning date minus the permit date for all plants in the Anlagenregister. This gives us a distribution of construction periods for German wind power plants. The average construction period is twelve months (see Figure A-1 in appendix A.2). Second, we approximate the missing permit dates in the Betreiber-Datenbasis by subtracting from the (known) construction date a random draw of the distribution of construction times. ${ }^{1}$ Since almost 99 percent of all wind turbines built after 2010 in Germany have a construction date below four years (cf. Figure A-1), we restrict the distributions from which we draw to 48 months in order to exclude extreme (possibly erroneous) observations. Lastly, we aggregate the turbine-specific information on the district level for every month.

The assumption underlying the approximation procedure is that the construction times for the plants for which we do have information on the permit date and the ones where we only have the construction date are similar. We provide evidence for this assumption by showing that the turbines in these two groups are very much alike in terms of height and power: These variables differ between both groups by around two percent (power) and by less than one percent (height) in a typical year (see appendix A.2).

\subsection{Descriptive Statistics}

Table 1 shows that only 7.7 percent of all building permits in the years 2010-2016 were granted to Bavarian wind turbines, although almost one-fourth of all German districts are located in Bavaria. Moreover, the average height of wind turbines of 190 meters in Bavaria implies that the $10 \mathrm{H}$ regulation translates into a separation distance of 1900 meters on average.

\footnotetext{
${ }^{1}$ Specifically, we draw from two separate yearly distributions, one containing all Bavarian wind turbines, and a second one containing all other German wind turbines. Draws are from yearly distributions of the construction periods, reflecting that the duration of the construction might change over time. However, the construction times for the years 2010-2014 are pooled into a joint distribution, because the number of observations with information on the construction period is low in the individual years.
} 
Table 1: Descriptive statistics of wind turbines in Bavaria and all of Germany

\begin{tabular}{lrr}
\hline & Bavaria & Germany \\
\hline Number of districts & 96 & 401 \\
Mean district area $\left[\mathrm{km}^{2}\right]$ & 734.8 & 891.7 \\
Number of wind turbines & 760 & 10,019 \\
Total added wind capacity [MW] & 1,986 & 25,125 \\
Mean power of wind turbines [MW] & 2.61 & 2.70 \\
Mean height of wind turbines [meter] & 190 & 171 \\
Mean number of permits per district & 0.25 & 0.81 \\
[MW/month] & & 11.6 \\
Mean construction period [months] & 14.9 & \\
\hline
\end{tabular}

The statistics refer to wind turbines from our permit database that received their construction permits between 2010 and 2016. The districts refer to Germany's territorial status as of September 30 2019.

Figure 2 illustrates the advantage of our new permit dataset. It shows how an analysis based on newly installed wind turbines would be biased. Bavarian construction permits, which are directly affected by the separation distances, declined sharply after November 2014. New installations of wind turbines, on the other hand, actually increased after the introduction of mandatory separation distances. Consequently, an analysis of the minimum distance regulation based on installation data would underestimate the effect of the policy.

Figure 2: Permits for wind turbines and newly installed wind power capacity in Bavaria

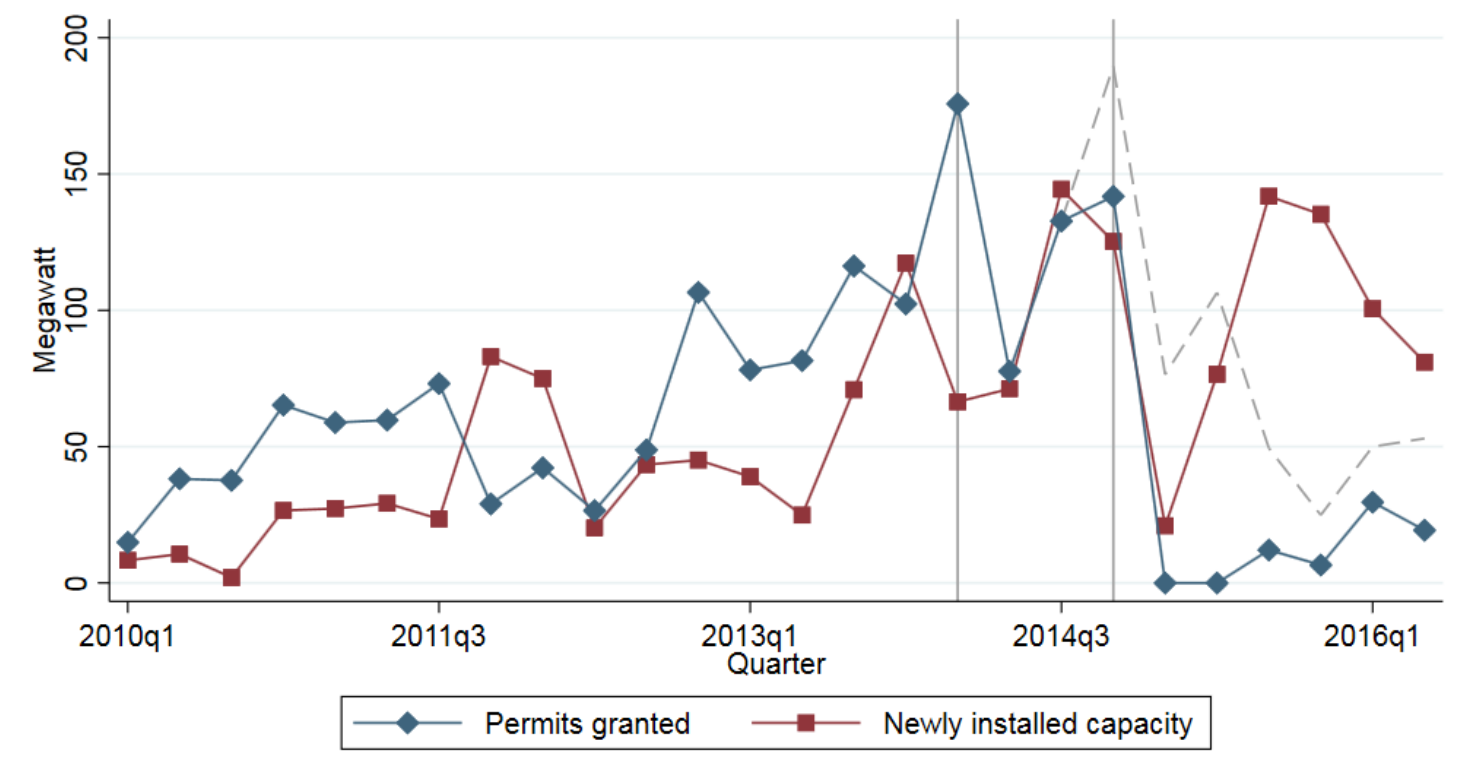

The figure shows the quarterly new construction permits and installations of wind power in Bavaria, as well as the cutoff dates of the introduction of the minimum distance regulation. Permits include the total number of permits (dashed line), or the permits under an application of the Bavarian minimum distance regulation only (blue solid line). The left vertical line marks the cut-off date to file for new permits that are not subject to strict separation distances in February 2014. The right vertical line indicates the introduction of the policy in November 2014. q1 denotes the first quarter for a given year. 


\section{Effect of minimum distances on wind power expansion}

\subsection{Identifying the causal effect}

We use a difference-in-differences model to identify the causal effect of the Bavarian separation distances on wind power expansion in Bavaria. The baseline specification is given by

$$
q_{i, t}^{W i n d}=\delta D_{i, t}+\mu_{i}+\tau_{t}+\varepsilon_{i, t}
$$

where the dependent variable $q$ is the number of wind turbine permits granted in district $i$ in month $t$ (in MW). $\mu_{i}$ is a district-level fixed effect that controls for those differences in the number of permits between districts that are constant over time. $\tau_{t}$ is a vector of month fixed effects, controlling for the impact of national shocks to the number of permits. Such shocks may include lower costs for building wind turbines over time, as well as changes to the German renewables remuneration regime that affect Bavaria and the rest of Germany similarly. $\delta$ is the coefficient of interest, measuring the effect of the $10 \mathrm{H}$ regulation on the number of permits in the average Bavarian district.

\subsection{Results}

The number of wind power permits issued in Bavaria dropped drastically after the minimum distance regulation was introduced. In most Bavarian districts, no permits for wind power plants were issued under the new minimum distance regulation in 2015 (see Figure 3). Although there were some minor changes in individual districts in other states as well, on average the other German states did not experience a similar decline. 
Figure 3: Wind permits before and after the introduction of minimum distances in Bavaria
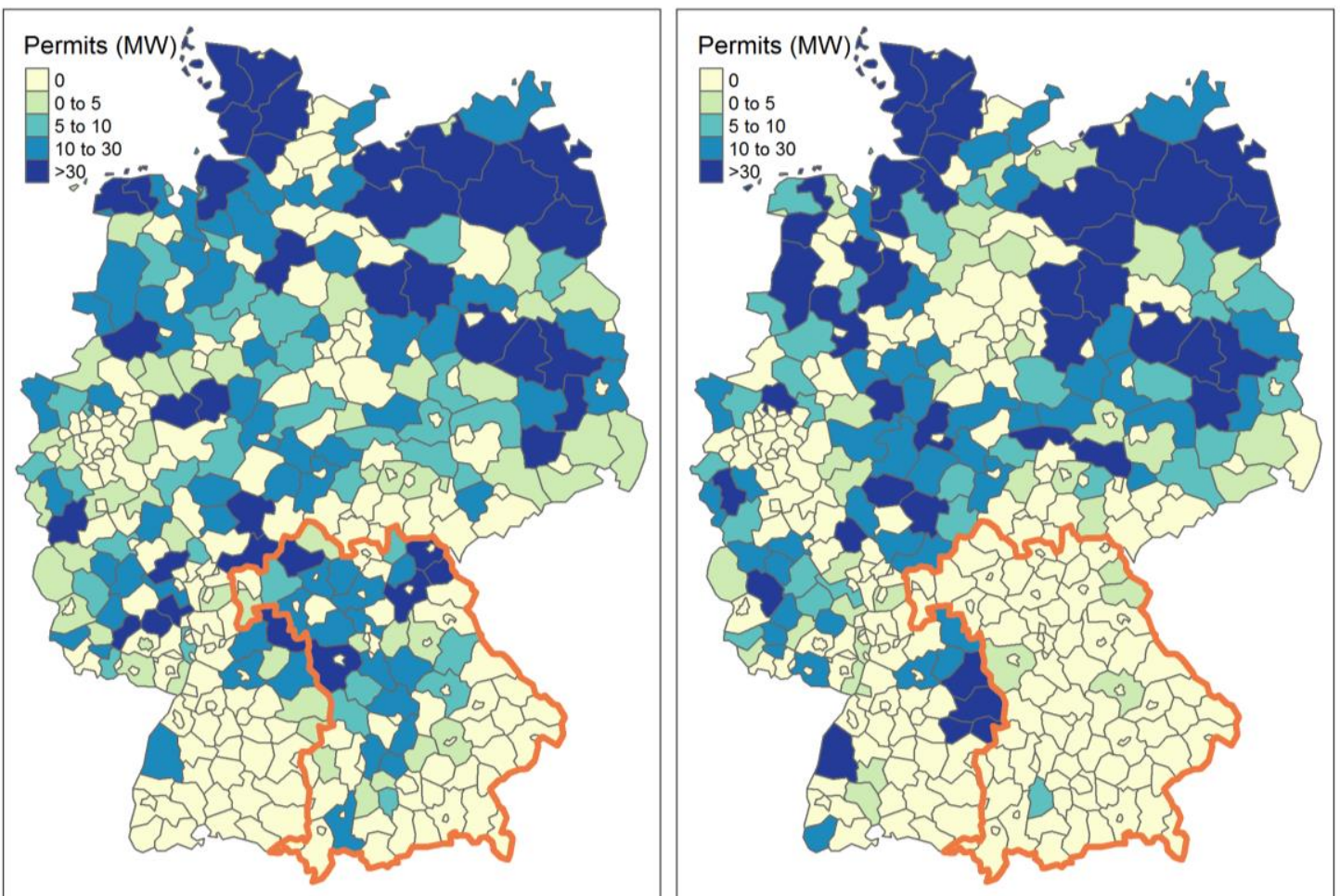

The figure shows the total number of permits for wind turbines (in megawatt) issued in the twelve months before the introduction of minimum distances in Bavaria (left panel), as well as the twelve months after (right panel). Permits in Bavaria (marked by the orange line) include the permits under an application of the Bavarian minimum distance regulation only.

Figure 4 illustrates that the number of construction permits issued in Bavaria and the rest of Germany followed a common trend before the introduction of the minimum distance regulation in November 2014. We substantiate this identifying assumption by implementing an event study design in appendix A.4. The event study approach provides strong support for the identifying assumption, namely that Bavarian permits would have evolved similarly to the rest of Germany, had the minimum distance regulation not been introduced (cf. Figure A-2 in the appendix).

The lower level of permits per district in Bavaria visible in Figure 4 results from the smaller district areas relative to districts in the rest of Germany (see Table 1). Moreover, average wind speeds are lower in Bavaria than in Northern Germany and parts of Central Germany (Deutscher Wetterdienst 2004). However, while the issuance of permits remained stable in Germany after November 2014, their number dropped strongly in Bavaria in the same period. This divergence is even more pronounced when focusing on the permits that were actually granted under the minimum distance regulation (solid line in Figure 4). 
Figure 4: Wind power permits in Bavaria and the rest of Germany

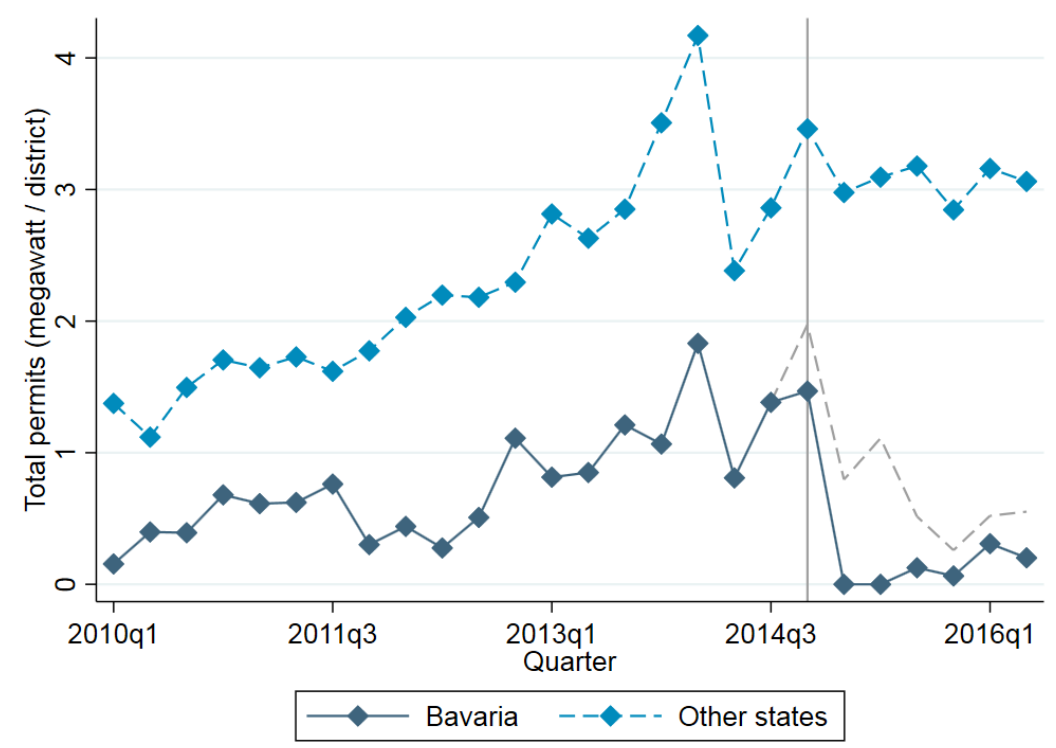

The graph shows the average number of permits for wind turbines (in megawatt) issued quarterly per district. Permits in Bavaria include the total number of permits (dashed line), or the permits under an application of the Bavarian minimum distance regulation only (solid line). q1 denotes the first quarter for a given year.

Our regressions show that the Bavarian regulation drastically reduced the number of construction permits. The regression results are presented in Table 2. All coefficients are highly statistically significant. Columns 3 and 6 correspond to the baseline specification (1) discussed in the previous section. The results are stable across specifications with different time fixed effects. The model with monthly fixed effects is our preferred specification (columns 3 and 6), since these take up more detailed variation than quarter and annual effects.

For the estimated treatment effects presented in Table 2, we also estimate the relative decrease of construction permits in Bavaria. We do this by comparing the point estimates to the number of permits that would be expected had the minimum distance policy not been in place. In other words, the treatment effect is compared to the counterfactual permits that we would expect in the average Bavarian district, had the $10 \mathrm{H}$ regulation not been implemented.

In our baseline specification, we assume that after the introduction of mandatory separation distances, wind turbines built under an exception from the $10 \mathrm{H}$ regulation would not have been built had the strict minimum distance rules been applied. Alternatively, a lower bound of the effect of the regulation can be calculated by assuming that all wind turbines that benefitted from such an exception would have survived the strict minimum distance rules. Under this alternative assumption, the estimated effect is lower, but remains statistically and economically highly significant.

We present the results from the lower bound estimations in columns 1-3 of Table 2). Under the strong assumption that all permits granted under exceptions from the Bavarian $10 \mathrm{H}$ regulation would have also been granted had the regulation been applied, the new mandatory separation distances reduced permits by around 0.34 megawatt (MW) per month per district, i.e. around 396 MW per year in Bavaria. This amounts to a reduction of the number of permits issued in Bavaria by 62 percent because of the introduction of strict minimum distances (column 3 of Table 2). 
This assumption underestimates the true effect of the Bavarian minimum distances. The separation distances strongly restricted the number of projects able to receive permits, making it unlikely that all of these projects would be in line with the new rules. Consequently, in columns 3-6 of Table 2, we re-estimate our models under the more realistic assumption that projects granted a permit without applying the $10 \mathrm{H}$ rule would not have received a permit had the $10 \mathrm{H}$ rules been enforced. In other words, we use only Bavarian wind turbines that did receive the permit under the new regulation after November 2014 in our estimation. Here, permits in Bavaria dropped by almost 0.5 MW per district per month (or 90 percent) in our preferred specification (column 6 of Table 2). Over the course of a year, this means that (summing over all districts) $571 \mathrm{MW}$ of wind power capacity were not installed in Bavaria. Our results are robust to the estimation of standard errors with an ordinary wild bootstrap procedure instead of the clustering at the state level (cf. appendix A.3). ${ }^{1}$

Table 2: Effect of minimum distances on wind power construction permits in Bavaria

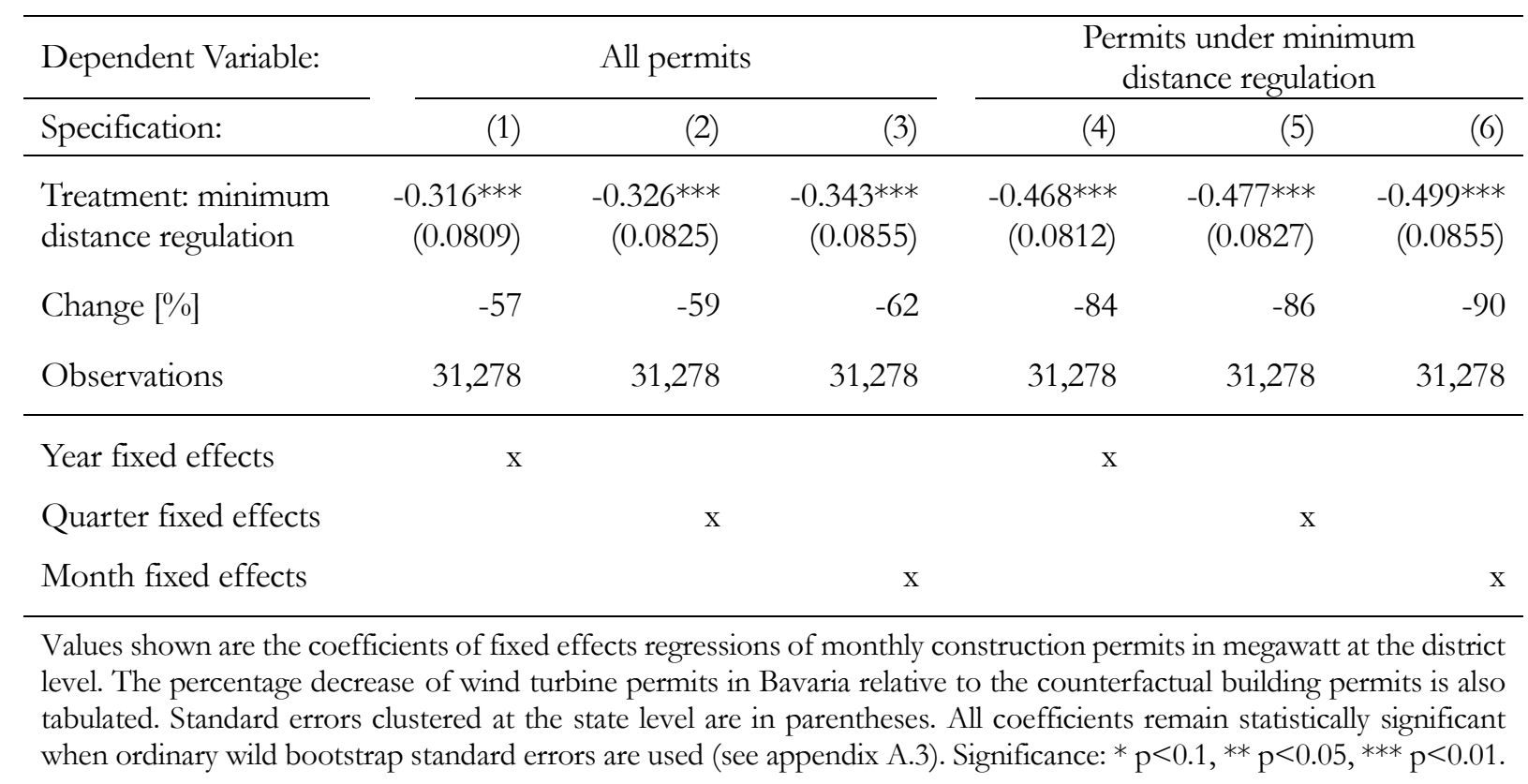

\subsection{Robustness checks}

We provide a battery of robustness checks, demonstrating that the main results shown in Table 2 hold. First, we run placebo regressions for all the four neighbouring states of Bavaria to demonstrate that our results can be attributed to the introduction of the separation distances. These regressions serve to rule out a general shock to wind expansion that also affected those southern German states, which have similarly mediocre wind speeds as Bavaria. Figure 5 visualises the regression results. The regression coefficients are statistically insignificant for all of the neighbouring states. This demonstrates that the change in the number of permits in Bavaria was caused by the introduction of the minimum distance regulation and not by random changes over time that affect states with

\footnotetext{
1 Although standard errors need to be clustered at the state level (Abadie et al. 2017), standard errors may be wrong due a low number of clusters (Cameron and Miller 2015). One solution to this is cluster bootstrapping, such as the wild cluster bootstrap. In the case of a small number of treated clusters, however, the wild cluster bootstrap often over-rejects or under-rejects severely (MacKinnon and Webb 2017). Thus, in appendix A.3 we compute p values based on the ordinary wild bootstrap (MacKinnon and Webb 2018).
} 
mediocre wind resources similarly. In other words, no general economic or policy shock that affected the other southern states can explain the observed effect in Bavaria. Moreover, the identified Bavarian coefficient is particularly large when considering that the state is divided into relatively many districts, such that individual districts are small (cf. Table 1).

Figure 5: Placebo regressions for neighbouring states of Bavaria

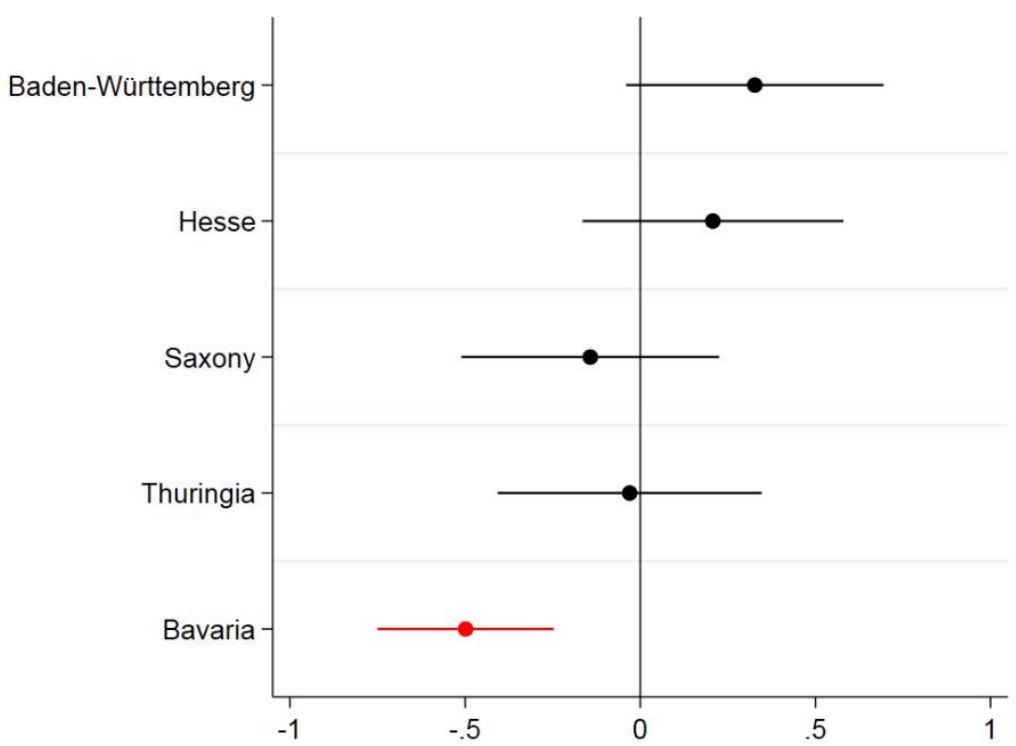

The figure compares the coefficients of placebo regressions for the neighbouring states of Bavaria to the baseline specification (Table 2, column 6), with standard errors at the $99 \%$ significance level.

Second, we demonstrate that our results are robust to possible anticipatory effects. If market participants reacted to the introduction of the $10 \mathrm{H}$ regime by increasingly filing for building permits before the new rules became effective, such anticipatory behaviour would confound our estimates. In order to exclude this possibility, we re-estimate model (1), taking into account potential anticipation effects by excluding observations within \pm 6 months and \pm 12 months of the introduction of the minimum distance regulation. The estimated relative treatment effect of the separation distances on permits in these specifications is almost identical to the main results in Table 2 , and the point estimates remain highly statistically significant. This confirms the findings of the baseline specification.

Third, we show that our findings are qualitatively robust to spillover effects. Identification relies on the Stable Unit Treatment Value Assumption (SUTVA), which implies there are no spillovers to the rest of Germany because of the introduction of minimum distances in Bavaria. However, it is conceivable that at least some of the wind projects that were not realised in Bavaria moved to other parts of Germany. This would confound our estimates. Table A-5 in appendix A.5 re-estimates some of the central specifications under the assumption that all wind turbines that were not built in Bavaria were immediately constructed elsewhere in the country. Even under this extreme assumption, the relative reduction of wind permits due to the $10 \mathrm{H}$ regulation remains virtually unchanged.

Finally, our results are robust to the approximation procedure of the construction periods. To show this, we re-estimate the models shown in Table 2 based on the subset of those plants where we do have information on the construction date from the Anlagenregister (see Table A-6 in appendix A.5). The estimated effects of the minimum distance regulations are even stronger in this specification. 
We therefore rule out that the approximation of permit dates from their construction dates for some of the wind turbines confounds our estimates.

Summing up, our main conclusions remain virtually unchanged under a range of specifications. This provides evidence for the robustness of our results.

\section{Minimum distances and land availability}

Our main finding of strong negative effects on new permits is in line with model-based estimates of the effect of minimum distances on the land available for wind power. Taking into account the preexisting regulation, introducing a minimum distance of 1000 meters would reduce the land area by 10 to 47 percent in Germany (see Figure 6). This reduction increases to 81 to 96 percent for a distance of 2000 meters. Moreover, the impact of minimum distances on available land varies considerably with the definition of the type of residential areas for which the separation distance holds (Umweltbundesamt 2019). Minimum distances towards individual housing reduce available land considerably more than distances only to larger settlements. For example, a strict definition of a minimum distance of 1000 meters can have effects similar to a less strict definition of 1300 meters (Figure 6). Hence, when analysing the effects of minimum distance regulation, it is crucial to specify the reference to which the distance applies.

Figure 6: Effect of minimum distance regulation on energy potential and land available for wind turbines in Germany

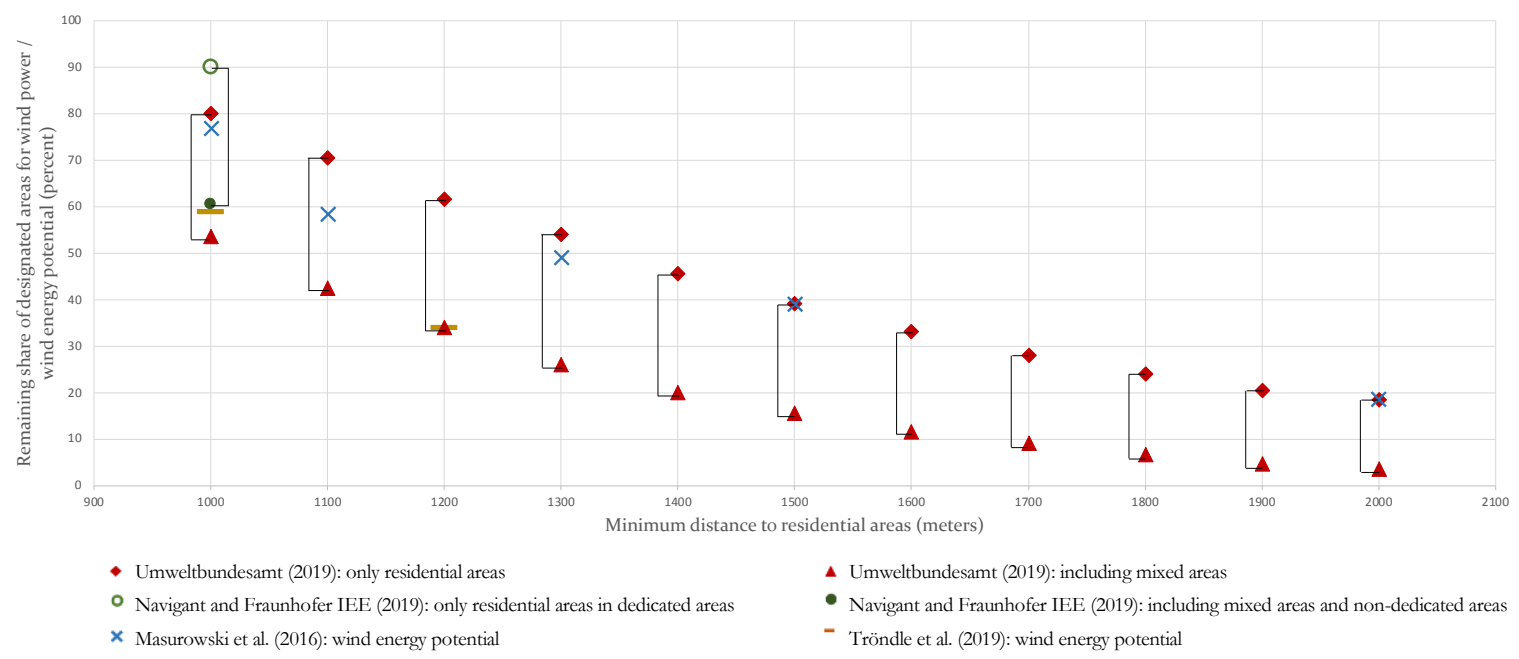

The figure displays the remaining share of land available for wind power as a function of different minimum distances, based on simulation studies. On the vertical axis, we depict the remaining share of the land dedicated to the construction of wind turbines in regional plans in Germany (Umweltbundesamt 2019; Navigant and Fraunhofer IEE 2019), and the remaining wind energy potential compared to a minimum distance baseline of 800 meters (Masurowski et al. 2016; Tröndle et al. 2019).

\section{Policies to support public acceptance of wind power}

In light of the massive extension plans for onshore wind power in many countries, maintaining and supporting local acceptance of wind power deployment is an important policy goal. However, the 
academic literature on public acceptance does not support the hypothesis of a significant uptake of public acceptance due to increased separation distances: On the one hand, wind turbines have been shown to exert negative externalities locally, for example on well-being of local residents (Krekel and Zerrahn 2017). Moreover, large accumulations of wind turbines nearby residential nearby residential areas affect acceptance negatively (Ladenburg et al. 2013; Ladenburg and Dahlgaard 2012; Ott and Keil 2017). However, the often-touted not-in-my-backyard (NIMBY) theory has been abandoned by the academic literature for a lack of explanatory power (Wolsink 2012; Zerrahn 2017). There is evidence that negative effects of wind turbines on well-being are transitory and disappear a few years after the installation (Krekel and Zerrahn 2017). In addition, there is no evidence that an increasing proximity to wind turbines exacerbates the negative external effects of wind turbines (Krekel and Zerrahn 2017; Langer et al. 2016, 2018; Rand and Hoen 2017; Hoen et al. 2019; Hübner et al. 2019). This indicates that increasing minimum distances will likely have no effect on the social acceptance of wind power.

One explanation for this paradox is that residents in many countries are already protected from noise, shadowing and visual impairment of wind turbines. In Germany, federal law mandates that project developers need to prove on a case-by-case basis that the effect of noise and other disturbances is limited (Wegner 2017). Consequently, increasing the (implicit) legal separation distances may not improve acceptance significantly. This might also explain why the identified willingness-to-pay for larger minimum distances is low and lies well below the additional costs of reducing the available land area under minimum distance regulation (Drechsler et al. 2017).

Procedural and distributional fairness are important determinants for public acceptance of renewables (Ellis and Ferraro 2016; Zerrahn 2017; Jørgensen et al. 2020). Regarding onshore wind power, one obstacle is that the economic benefits mostly accrue where manufacturers, project developers and related companies are based, rather than where the turbines are located (May and Nilsen 2019). One solution is to address this issue by financially compensating local residents or communities. Denmark and the German state of Mecklenburg Western Pomerania have implemented investment opportunities for residents that live close to the turbines. The German federal state of Brandenburg, on the other hand, has introduced mandatory annual payments to local municipalities (Stede and May 2019). Choice experiments and surveys from Germany, Norway and Switzerland suggest that annual payments to local municipalities are preferred to investment opportunities for individual residents and can help to increase acceptance for new wind turbines (García et al. 2016; FA Wind 2019; Vuichard et al. 2019).

\section{Conclusion}

Minimum distance regulations between wind turbines and residential areas have been introduced and discussed for many regions and countries around the world, but their causal effects on new wind power projects have not been assessed. Since no comprehensive dataset of wind power permits for Germany existed, research on separation distances so far was limited to descriptive analyses. We address this issue by providing a newly compiled dataset, comprising all permits granted to wind power installations that were installed between 2010 and 2018 in Germany. We use these data to provide causal evidence that minimum distance regulation in the federal state of Bavaria reduced the deployment of wind power by up to 90 percent. This indicates that the increased separation distance 
not only strongly reduced the land available for wind power deployment, but decreased the number of new installations in the same order of magnitude.

For policymakers, this research shows that separation distances not only reduce land available for wind power deployment, but may translate into drastic reductions of new installations. Possible local exemptions from the regulation were not able to reverse this effect in the case of Bavaria. There is also no evidence that tighter separation distances have a significant effect on public acceptance of wind turbines. Direct payments to local municipalities, on the other hand, address the externalities of wind turbines more directly. Such financial compensation improves public acceptance by allowing the communities that are directly affected to participate in the value added of wind power generation.

For researchers, this chapter has three implications. First, our new dataset on all permits issued for onshore wind power in Germany allows researchers to analyse the effects of various policies that address permission processes rather than installations. This includes, for example, the introduction of environmental regulation, or the opposition by local anti-wind power groups. Second, researchers could look at the introduction of mandatory separation distances in other countries such as Scotland (2010) and Poland (2016), in order to evaluate whether the results of this chapter extend to other jurisdictions. Third, as the number of installations grows, ensuring public acceptance of onshore wind power becomes increasingly important. Therefore, regulatory frameworks are needed that facilitate acceptance without hampering the expansion of wind power. Towards this end, analysing the effects of local investment participation on public acceptance and deployment of wind power is an interesting venue for future research. 


\section{Appendix}

\section{A.1. Timing and legal treatment of the minimum distance regulation}

Timeline of introduction. The $10 \mathrm{H}$ regulation came into effect on November $21^{\text {st }}, 2014$. New permits granted for wind turbines after this date had to adhere to the distance regulation in principle. However, when project developers had filed for permits before February $4^{\text {th }}, 2014$, a permit could still be granted without considering the $10 \mathrm{H}$ regulation if the decision on the permit was taken until the end of 2015. This also implied that filings that happened in between these dates could be evaluated differently according to the decision date: In case that the filings were still evaluated before November $21^{\text {st }}$, the old regulation was applied. If decisions were taken by the relevant authority after the cut-off date, the $10 \mathrm{H}$ regulation applied.

Legal treatment. The $10 \mathrm{H}$ regulation is widely discussed and understood as a minimum distance regulation. Legally, the regulation took away the prioritization of wind power in the buildings code. In Germany, wind power is prioritized outside of residential areas and municipalities assign specific areas for wind power deployment. The regulation removed this prioritization. However, individual counties could decide to keep the preferential treatment of wind power in their local planning processes. Permits granted under such exemptions, together with the permits for filings before February $4^{\text {th }}, 2014$, are reflected in the specifications shown in columns (1-3) in Table 2. These estimations rely on the assumption that even in the absence of the exemptions or had the filings been made only later, all permits would also have been granted under the strict application of the 10 $\mathrm{H}$ regulation. Thus, these estimates are a lower bound of the effect of the Bavarian minimum distance regulation.

\section{A.2. Approximation of permit date}

Table A-1 provides evidence that wind turbines with and without information on the date of the permit are very similar Within the periods from which we use the distributions to approximate the construction date (i.e. 2010-2014, 2015 and 2016), the two variables power and height differ on average by 2.4 percent (power) and 0.8 percent (height). Moreover, we show the overall distribution of the construction period in Figure A-1, illustrating that the average wind turbine takes one year to build. Figure A-1 also illustrates that the vast majority of wind power plants (more than 94 percent) are constructed within less than two years. 
Table A-1: Comparison of wind turbines with and without information on the date of the building permit

\begin{tabular}{|c|c|c|c|c|c|c|}
\hline & \multicolumn{3}{|c|}{$\begin{array}{l}\text { Turbines with information on } \\
\text { the date of the permit }\end{array}$} & \multicolumn{3}{|c|}{$\begin{array}{l}\text { Turbines without information on } \\
\text { the date of the permit }\end{array}$} \\
\hline & Power & Height & $\mathrm{N}$ & Power & Height & $\mathrm{N}$ \\
\hline 2010-2014 & 2.65 & 165 & 1,653 & 2.52 & 163 & 4,429 \\
\hline 2010 & 2.12 & 138 & 209 & 2.23 & 150 & 649 \\
\hline 2011 & 2.22 & 148 & 107 & 2.38 & 155 & 860 \\
\hline 2012 & 2.81 & 170 & 109 & 2.55 & 162 & 1,009 \\
\hline 2013 & 2.73 & 164 & 307 & 2.66 & 167 & 1,182 \\
\hline 2014 & 2.77 & 172 & 921 & 2.68 & 175 & 729 \\
\hline 2015 & 2.81 & 182 & 814 & 2.81 & 182 & 590 \\
\hline 2016 & 3.03 & 183 & 1,902 & 2.96 & 185 & 631 \\
\hline
\end{tabular}

The table displays average power (in megawatt) and average height (in meters) by the year in which the building permits were granted.

Figure A-1: Distribution of construction periods of wind turbines in Germany

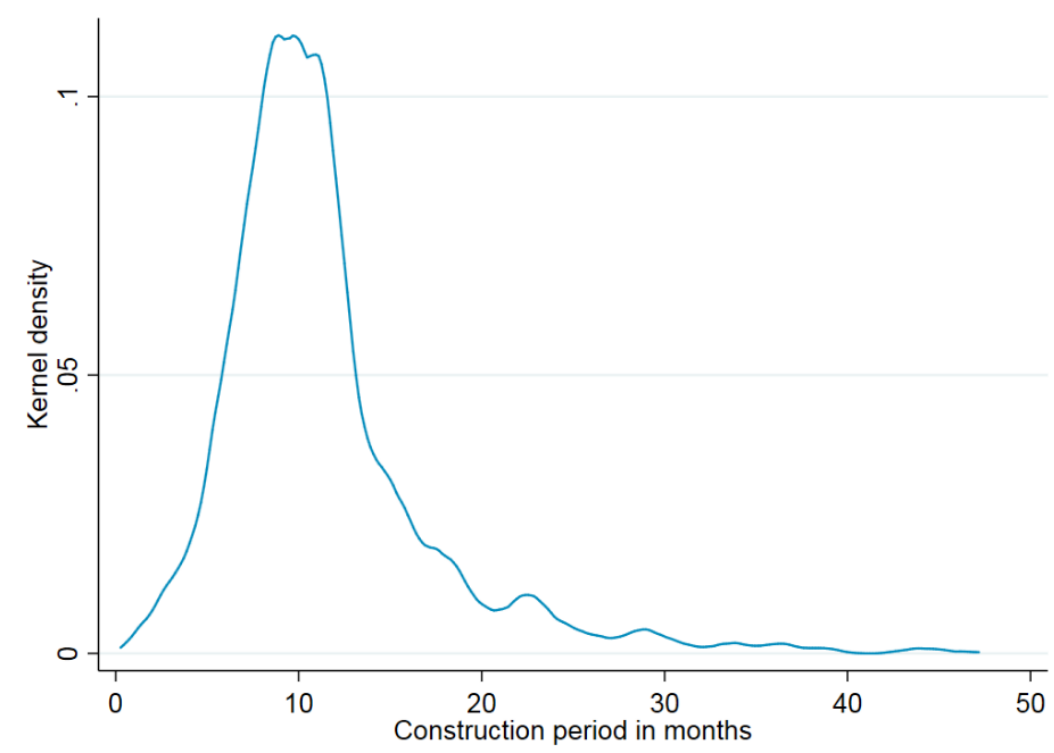

The graph depicts the Kernel density of the construction period of German wind turbines in the years 2010-2017 according to the Anlagenregister. The construction period is defined as the number of months elapsed between the issuance of the building permit of a wind turbine and the completion of its construction.

\section{A.3. Bootstrapped standard errors}

Our results are robust to the estimation of standard errors with an ordinary wild bootstrap procedure instead of the clustering at the state level. In general, since the treatment (the minimum distance regulation) is assigned at the federal state level, standard errors need to be clustered at the state level (Abadie et al. 2017). However, as Germany consists of 16 states, there are only few clusters, which 
means the standard errors may be wrong (Cameron and Miller 2015). One solution to this is cluster bootstrapping, such as the wild cluster bootstrap. In the case of a small number of treated clusters, however, the wild cluster bootstrap often over-rejects or under-rejects severely (MacKinnon and Webb 2017). Thus, we compute $\mathrm{p}$ values for the models estimated in Table 2 based on the ordinary wild bootstrap (MacKinnon and Webb 2018). The statistical level of significance remains at the one percent level for the preferred specification including all Bavarian wind turbines (column 3 of Table A-2). In the preferred specification with only Bavarian wind turbines that received permits under the $10 \mathrm{H}$ regime, the level of significance of the ordinary wild bootstrap is even higher $(0.1 \%$ level, column 3 of Table A-2).

Table A-2: Bootstrap standard errors: Effect of minimum distances on wind permits in Bavaria

\begin{tabular}{|c|c|c|c|c|c|c|}
\hline Dependent Variable: & \multicolumn{3}{|c|}{ All permits } & \multicolumn{3}{|c|}{$\begin{array}{l}\text { Permits under minimum } \\
\text { distance regulation }\end{array}$} \\
\hline Specification: & (1) & (2) & (3) & (4) & (5) & (6) \\
\hline $\begin{array}{l}\text { Treatment: Minimum } \\
\text { distance regulation }\end{array}$ & -0.316 & -0.326 & -0.343 & -0.468 & -0.477 & -0.499 \\
\hline $\mathrm{p}$ value - state cluster & 0.0014 & 0.0013 & 0.0011 & 0.0000 & 0.0000 & 0.0000 \\
\hline $\begin{array}{l}\mathrm{p} \text { value - ordinary wild } \\
\text { bootstrap }\end{array}$ & 0.0080 & 0.0180 & 0.0030 & 0.0000 & 0.0010 & 0.0010 \\
\hline Observations & 31,278 & 31,278 & 31,278 & 31,278 & 31,278 & 31,278 \\
\hline Year fixed effects & $\mathrm{x}$ & & & $\mathrm{x}$ & & \\
\hline Quarter fixed effects & & $\mathrm{x}$ & & & $\mathrm{x}$ & \\
\hline Month fixed effects & & & $\mathrm{x}$ & & & $\mathrm{x}$ \\
\hline
\end{tabular}

Values shown are the coefficients and $\mathrm{p}$ values of fixed effects regressions of monthly construction permits in megawatt at the district level. P values are clustered at the state level and computed with the ordinary wild bootstrap, respectively. The ordinary wild bootstrap uses 999 replications and Rademacher weights.

\section{A.4. Event study}

The main identifying assumption underlying the difference-in-differences model is that the number of permits granted in Bavaria and the rest of Germany follow a common trend. A visual inspection of Figure 4 supports this hypothesis. Moreover, we implement an event study approach given by

$$
q_{i, t}^{\text {Wind }}=\sum_{j=-m}^{s} \delta_{j} D_{i, t+j}+\mu_{i}+\tau_{t}+\varepsilon_{i, t}
$$

where $m$ "leads" and $s$ "lags" of the treatment effect are included instead of the single treatment effect in (1).

Figure A-2 provides strong evidence for the validity of the main identifying assumption, namely that Bavarian permits would have evolved similarly to the rest of Germany, had the minimum distance regulation not been introduced. The graph shows that there was no statistical difference between the trend of wind permits in Bavaria and the rest of Germany in any of the 12 months before the 
$10 \mathrm{H}$ rule became effective. After the introduction of the $10 \mathrm{H}$ regime, on the other hand, all interactions of the treatment with time lags to the reform are statistically significant.

Figure A-2: Event study: Effect of minimum distances on wind permits in Bavaria

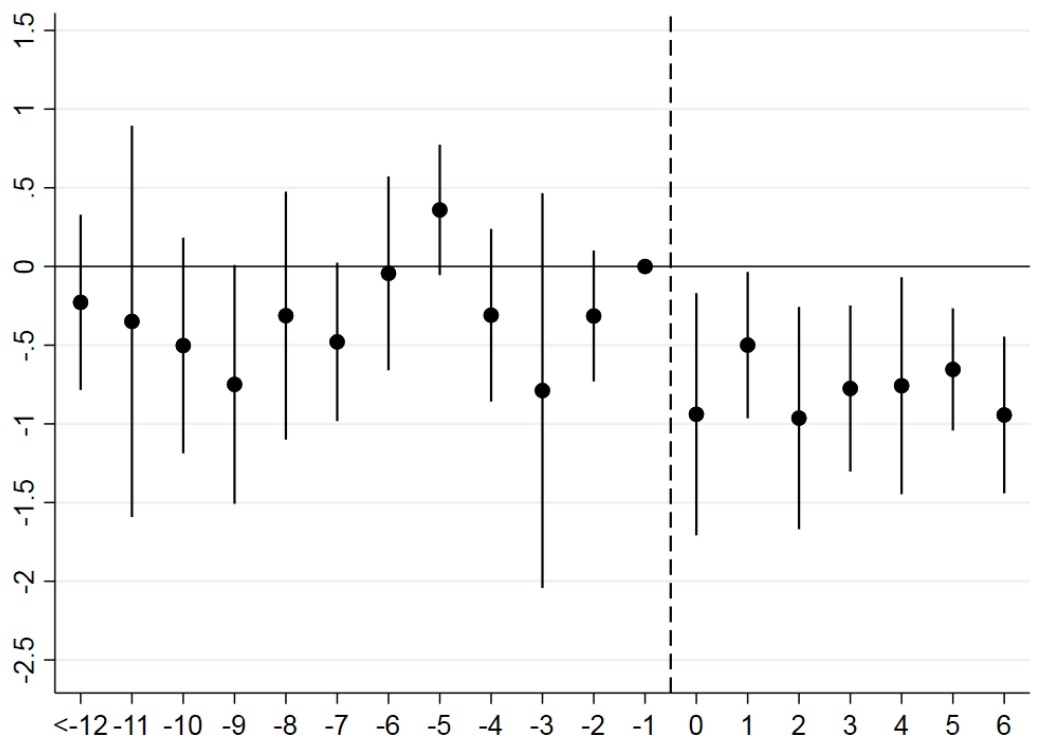

The figure plots coefficient estimates and 99\% confidence intervals from an interaction of the reform with indicators on the time difference to the reform (in months). For Bavaria, only permits granted under an application of the minimum distance regulation are included in the regression. The dashed line marks the introduction of the reform in November 2014.

\section{A.5. Further robustness checks}

\section{Anticipation effects}

Tables A-3 and A-4 re-estimate the specifications shown in Table 2, excluding observations before and after the introduction of the $10 \mathrm{H}$ rule within a window of six and twelve months, respectively. All coefficients are still highly statistically significant. In our preferred specifications with only Bavarian wind turbines that received permits under the $10 \mathrm{H}$ regulation (column 6 of Tables A-3 and A-4), the relative effect size is virtually unchanged compared to Table 2 . In the specification including all Bavarian wind turbines, the effect is even larger, rising to around 70 percent in the robustness checks (column 3 of Tables A-3 and A-4). This shows that our results are robust to possible anticipation effects. 
Table A-3: Effect of minimum distances on permits, excluding six months window

\begin{tabular}{|c|c|c|c|c|c|c|}
\hline \multirow{2}{*}{$\begin{array}{l}\text { Dependent Variable: } \\
\text { Specification: }\end{array}$} & \multicolumn{3}{|c|}{ All permits } & \multicolumn{3}{|c|}{$\begin{array}{l}\text { Permits under minimum } \\
\text { distance regulation }\end{array}$} \\
\hline & (1) & $(2)$ & (3) & (4) & $(5)$ & (6) \\
\hline $\begin{array}{l}\text { Treatment: Minimum } \\
\text { distance regulation }\end{array}$ & $\begin{array}{r}-0.378^{* * *} \\
(0.119)\end{array}$ & $\begin{array}{r}-0.378^{* * *} \\
(0.119)\end{array}$ & $\begin{array}{r}-0.378^{* * *} \\
(0.119)\end{array}$ & $\begin{array}{r}-0.482^{* * *} \\
(0.119)\end{array}$ & $\begin{array}{r}-0.482^{* * *} \\
(0.119)\end{array}$ & $\begin{array}{r}-0.482^{* * *} \\
(0.119)\end{array}$ \\
\hline Change $[\%]$ & -71 & -71 & -71 & -90 & -90 & -90 \\
\hline Observations & 26,466 & 26,466 & 26,466 & 26,466 & 26,466 & 26,466 \\
\hline Year fixed effects & $\mathrm{x}$ & & & $\mathrm{x}$ & & \\
\hline Quarter fixed effects & & $\mathrm{x}$ & & & $\mathrm{x}$ & \\
\hline Month fixed effects & & & $\mathrm{x}$ & & & $\mathrm{x}$ \\
\hline
\end{tabular}

Table A-4: Effect of minimum distances on permits, excluding twelve months window

\begin{tabular}{|c|c|c|c|c|c|c|}
\hline \multirow{2}{*}{$\begin{array}{l}\text { Dependent Variable: } \\
\text { Specification: }\end{array}$} & \multicolumn{3}{|c|}{ All permits } & \multicolumn{3}{|c|}{$\begin{array}{c}\text { Permits under minimum } \\
\text { distance regulation }\end{array}$} \\
\hline & (1) & (2) & (3) & (4) & (5) & (6) \\
\hline $\begin{array}{l}\text { Treatment: Minimum } \\
\text { distance regulation }\end{array}$ & $\begin{array}{r}-0.419 * * * \\
(0.0958)\end{array}$ & $\begin{array}{r}-0.419 * * * \\
(0.0958)\end{array}$ & $\begin{array}{r}-0.419 * * * \\
(0.0959)\end{array}$ & $\begin{array}{r}-0.515^{* * *} \\
(0.0958)\end{array}$ & $\begin{array}{r}-0.515^{* * *} \\
(0.0958)\end{array}$ & $\begin{array}{r}-0.515^{* * *} \\
(0.0959)\end{array}$ \\
\hline Change $[\%]$ & -71 & -71 & -71 & -88 & -88 & -88 \\
\hline Observations & 21,654 & 21,654 & 21,654 & 21,654 & 21,654 & 21,654 \\
\hline Year fixed effects & $\mathrm{x}$ & & & $\mathrm{x}$ & & \\
\hline Quarter fixed effects & & $\mathrm{x}$ & & & $\mathrm{x}$ & \\
\hline Month fixed effects & & & $\mathrm{x}$ & & & $\mathrm{x}$ \\
\hline
\end{tabular}

\section{Spillover effects}

Table A-5 shows that our findings are qualitatively robust to spillover effects. We re-estimate the treatment effects under the assumption that all wind turbines that were not built in Bavaria were immediately constructed elsewhere in the country. The estimation is implemented by reducing the wind permits of all other German states by the amount of permits not issued in Bavaria and reestimating the models of Table 2 based on these reduced permits. As can be seen from Table A-5, the point estimates of the treatment effect decrease in this scenario relative to the main specifications in Table 2. However, the relative reduction of construction permits in Bavaria remains virtually 
unchanged (-88 percent in the preferred specification). The reason is that the counterfactual development of Bavarian permits decreases when permits in the rest of Germany are assumed to be lower.

Table A-5: Effect of minimum distances on permits, correcting for possible spillover effects

\begin{tabular}{|c|c|c|c|c|c|c|}
\hline \multirow{2}{*}{$\begin{array}{l}\text { Dependent Variable: } \\
\text { Specification: }\end{array}$} & \multicolumn{3}{|c|}{ All permits } & \multicolumn{3}{|c|}{$\begin{array}{l}\text { Permits under minimum } \\
\text { distance regulation }\end{array}$} \\
\hline & (1) & (2) & (3) & (4) & (5) & (6) \\
\hline $\begin{array}{l}\text { Treatment: Minimum } \\
\text { distance regulation }\end{array}$ & $\begin{array}{r}-0.222^{* *} \\
(0.0799)\end{array}$ & $\begin{array}{r}-0.229 * * \\
(0.0813)\end{array}$ & $\begin{array}{r}-0.235^{* *} \\
(0.0833)\end{array}$ & $\begin{array}{r}-0.328 * * * \\
(0.0805)\end{array}$ & $\begin{array}{r}-0.332 * * * \\
(0.0819)\end{array}$ & $\begin{array}{r}-0.342 * * * \\
(0.0834)\end{array}$ \\
\hline Change $[\%]$ & -50 & -51 & -52 & -84 & -85 & -88 \\
\hline Observations & 31,278 & 31,278 & 31,278 & 31,278 & 31,278 & 31,278 \\
\hline Year fixed effects & $x$ & & & $x$ & & \\
\hline Quarter fixed effects & & $x$ & & & $\mathrm{x}$ & \\
\hline Month fixed effects & & & $x$ & & & $\mathrm{x}$ \\
\hline \multicolumn{7}{|c|}{$\begin{array}{l}\text { Values shown are the coefficients of fixed effects regressions of monthly construction permits in megawatt at the district } \\
\text { level. The regressions correct for a hypothetical full spillover, under the extreme assumption that all wind turbines not } \\
\text { built in Bavaria were directly built elsewhere in Germany. To implement this, permit data in non-Bavarian districts are } \\
\text { reduced by the difference between predicted permits (according to the common trend assumption) and actual permits } \\
\text { in Bavaria. The percentage decrease of building permits in Bavaria relative to the counterfactual is also tabulated. Standard } \\
\text { errors clustered at the state level are in parentheses. Significance: } * p<0.1,{ }^{* *} p<0.05, * * * p<0.01 \text {. }\end{array}$} \\
\hline
\end{tabular}

\section{Regressions without approximation of permit date}

Our regression results also hold when we restrict the sample to only those observations where we have information on both the date of construction and the permit date from the Anlagenregister. To show this, we reproduce our results from Table 2 using only installations where we have information on both construction date and permit date. The results are qualitatively the same, but the effect of the $10 \mathrm{H}$ regulation is even more pronounced: With this subset of installations, it rises to -78 percent (all permits), and -94 percent (10 H permits only, see columns 3 and 6 of Table A-6). 
Table A-6: Effect of minimum distances on permits, using only turbine data with full information on the construction permit date

\begin{tabular}{|c|c|c|c|c|c|c|}
\hline \multirow{2}{*}{$\begin{array}{l}\text { Dependent Variable: } \\
\text { Specification: }\end{array}$} & \multicolumn{3}{|c|}{ All permits } & \multicolumn{3}{|c|}{$\begin{array}{l}\text { Permits under minimum } \\
\text { distance regulation }\end{array}$} \\
\hline & (1) & (2) & (3) & (4) & (5) & (6) \\
\hline $\begin{array}{l}\text { Treatment: Minimum } \\
\text { distance regulation }\end{array}$ & $\begin{array}{r}-0.572 * * * \\
(0.0894)\end{array}$ & $\begin{array}{r}-0.588^{* * *} \\
(0.0912)\end{array}$ & $\begin{array}{r}-0.647 * * * \\
(0.106)\end{array}$ & $\begin{array}{r}-0.701 * * * \\
(0.0894)\end{array}$ & $\begin{array}{r}-0.715^{* * *} \\
(0.0909)\end{array}$ & $\begin{array}{r}-0.781 * * * \\
(0.106)\end{array}$ \\
\hline Change $[\%]$ & -69 & -71 & -78 & -84 & -86 & -94 \\
\hline Observations & 31,278 & 31,278 & 31,278 & 31,278 & 31,278 & 31,278 \\
\hline Year fixed effects & $\mathrm{x}$ & & & $\mathrm{x}$ & & \\
\hline Quarter fixed effects & & $\mathrm{x}$ & & & $\mathrm{x}$ & \\
\hline Month fixed effects & & & $\mathrm{x}$ & & & $x$ \\
\hline
\end{tabular}

For this table, we re-estimate the treatment effects of Table 2, using only wind turbine from the Anlagenregister that have information on the date of the building permit of the wind turbine. We thus discard all observations with an approximated permit date. Values shown are the coefficients of fixed effects regressions of monthly construction permits in megawatt at the district level. The percentage decrease of building permits in Bavaria relative to the counterfactual is also tabulated. Standard errors clustered at the state level are in parentheses. Significance: ${ }^{*} \mathrm{p}<0.1,{ }^{* *} \mathrm{p}<0.05,{ }^{* * *} \mathrm{p}<0.01$. 


\section{Acknowledgements}

We thank Mathias Huebener, Jürgen Quentin, Nolan Ritter, Wolf-Peter Schill and Pascal Vuichard, as well as seminar participants at DIW Berlin and the Hertie School of Governance for helpful comments and suggestions. We also thank Katharina Erdmann and Friedemann Gruner for superb research assistance.

This research did not receive any specific grant from funding agencies in the public, commercial, or not-for-profit sectors. 


\section{References}

Abadie, A., Athey, S., Imbens, G.W., Wooldridge, J., 2017. When should you adjust standard errors for clustering? (NBER Working Paper No. 24003). National Bureau of Economic Research. Accessed December 19, 2019, from <https://www.nber.org/papers/w24003.pdf>

Bataille, C., Åhman, M., Neuhoff, K., Nilsson, L.J., Fischedick, M., Lechtenböhmer, S., SolanoRodriquez, B., Denis-Ryan, A., Stiebert, S., Waisman, H., Sartor, O., Rahbar, S., 2018. A review of technology and policy deep decarbonization pathway options for making energyintensive industry production consistent with the Paris Agreement. J. Clean. Prod. 187, 960973.

Betreiber-Datenbasis, 2019. Register/Errichtungsdaten deutscher Windanlagen. Accessed from $<$ http://www.btrdb.de/>

BMWi, 2020. Time series for the development of renewable energy sources in Germany 2010-2019. Federal Ministry for Economic Affairs and Energy, Berlin / Dessau-Roßlau. Accessed April 14, 2020, from <https://www.erneuerbareenergien.de/EE/Redaktion/DE/Downloads/zeitreihen-zur-entwicklung-dererneuerbaren-energien-in-deutschland-1990-2019-en.pdf?_blob=publicationFile\&v=10>

Cameron, A.C., Miller, D.L., 2015. A practitioner's guide to cluster-robust inference. J. Hum. Resour. $50,317-372$.

Cashmore, M., Rudolph, D., Larsen, S.V., Nielsen, H., 2019. International experiences with opposition to wind energy siting decisions: lessons for environmental and social appraisal. J. Environ. Plan. Manag. 62, 1109-1132.

Chu, S., Majumdar, A., 2012. Opportunities and challenges for a sustainable energy future. Nature 488, 294-303.

Deutsche Windguard, 2019. Status des Windenergieausbaus an Land in Deutschland - Jahr 2018. Accessed February 20, 2020, from <https://www.windenergie.de/fileadmin/redaktion/dokumente/pressemitteilungen/2019/20190129_Factshee t_Status_des_Windenergieausbaus-Jahr_2018.pdf>

Deutscher Wetterdienst, 2004. Windkarten zur mittleren Windgeschwindigkeit. Accessed January 16, 2020 ,

from $<$ https://www.dwd.de/DE/leistungen/windkarten/deutschland_und_bundeslaender.html $>$

Drechsler, M., Egerer, J., Lange, M., Masurowski, F., Meyerhoff, J., Oehlmann, M., 2017. Efficient and equitable spatial allocation of renewable power plants at the country scale. Nat. Energy $2,17124$.

Egli, F., Steffen, B., Schmidt, T.S., 2018. A dynamic analysis of financing conditions for renewable energy technologies. Nat. Energy 3, 1084-1092.

Ellis, G., Ferraro, G., 2016. The social acceptance of wind energy (JRC Science for Policy Report No. EUR $28182 \mathrm{EN})$. Accessed from < https://dx.doi.org/10.2789/696070>

FA Wind, 2019. Umfrage zur Akzeptanz der Windenergie an Land Herbst 2019. Accessed March 20, 2020, from <https://www.fachagenturwindenergie.de/fileadmin/files/Veroeffentlichungen/FA_Wind_Umfrageergebnisse_2019. pdf $>$

Fraunhofer IEE, 2019. Windenergie Report Deutschland 2018. Accessed April 28, 2020, from $<$ http://windmonitor.iee.fraunhofer.de/windmonitor_de/5_Veroeffentlichungen/1_winde nergiereport $/>$

García, J.H., Cherry, T.L., Kallbekken, S., Torvanger, A., 2016. Willingness to accept local wind energy development: Does the compensation mechanism matter? Energy Policy 99, 165-173.

German Federal Government, 2019. Klimaschutzprogramm 2030 der Bundesregierung zur Umsetzung des Klimaschutzplans 2050. Berlin. Accessed December 20, 2019, from 
<https://www.bmu.de/fileadmin/Daten_BMU/Download_PDF/Klimaschutz/klimaschu tzprogramm_2030_umsetzung_klimaschutzplan.pdf>

Hoen, B., Firestone, J., Rand, J., Elliot, D., Hübner, G., Pohl, J., Wiser, R., Lantz, E., Haac, T.R., Kaliski, K., 2019. Attitudes of US Wind Turbine Neighbors: Analysis of a Nationwide Survey. Energy Policy 134, 110981.

Hübner, G., Pohl, J., Hoen, B., Firestone, J., Rand, J., Elliott, D., Haac, R., 2019. Monitoring annoyance and stress effects of wind turbines on nearby residents: A comparison of U.S. and European samples. Environ. Int. 132, 105090.

IEA, 2019. World Energy Outlook 2019. OECD, Paris. Accessed from $<$ https://doi.org/10.1787/20725302>

IPCC, 2018. Mitigation pathways compatible with $1.5^{\circ} \mathrm{C}$ in the context of sustainable development, in: Masson-Delmotte, V., et al. (Eds.), Global Warming of $1.5^{\circ} \mathrm{C}$. An IPCC Special Report on the Impacts of Global Warming of $1.5^{\circ} \mathrm{C}$ above Pre-Industrial Levels and Related Global Greenhouse Gas Emission Pathways, in the Context of Strengthening the Global Response to the Threat of Climate Change, Sustainable Development, and Efforts to Eradicate Poverty. In Press.

IRENA, 2019. Renewable Power Generation Costs in 2018. International Renewable Energy Agency, Abu Dhabi. Accessed December 20, 2019, from <https://www.irena.org//media/Files/IRENA/Agency/Publication/2019/May/IRENA_Renewable-PowerGenerations-Costs-in-2018.pdf>

Jørgensen, M.L., Anker, H.T., Lassen, J., 2020. Distributive fairness and local acceptance of wind turbines: The role of compensation schemes. Energy Policy 138, 111294.

Krekel, C., Zerrahn, A., 2017. Does the presence of wind turbines have negative externalities for people in their surroundings? Evidence from well-being data. J. Environ. Econ. Manag. 82, 221-238.

Ladenburg, J., Dahlgaard, J.-O., 2012. Attitudes, threshold levels and cumulative effects of the daily wind-turbine encounters. Appl. Energy 98, 40-46.

Ladenburg, J., Termansen, M., Hasler, B., 2013. Assessing acceptability of two onshore wind power development schemes: A test of viewshed effects and the cumulative effects of wind turbines. Energy 54, 45-54.

Langer, K., Decker, T., Roosen, J., Menrad, K., 2018. Factors influencing citizens' acceptance and non-acceptance of wind energy in Germany. J. Clean. Prod. 175, 133-144.

Langer, K., Decker, T., Roosen, J., Menrad, K., 2016. A qualitative analysis to understand the acceptance of wind energy in Bavaria. Renew. Sustain. Energy Rev. 64, 248-259.

MacKinnon, J.G., Webb, M.D., 2018. The wild bootstrap for few (treated) clusters. Econom. J. 21, 114-135.

MacKinnon, J.G., Webb, M.D., 2017. Wild bootstrap inference for wildly different cluster sizes. J. Appl. Econom. 32, 233-254.

Masurowski, F., Drechsler, M., Frank, K., 2016. A spatially explicit assessment of the wind energy potential in response to an increased distance between wind turbines and settlements in Germany. Energy Policy 97, 343-350.

May, N., Nilsen, Ø.A., 2019. The Local Economic Impact of Wind Power Deployment. Finanz. Public Finance Anal. 75, 56-92.

Mitchell, C., 2016. Momentum is increasing towards a flexible electricity system based on renewables. Nat. Energy 1, 1-6.

Navigant, Fraunhofer IEE, 2019. Wissenschaftliche Fundierung der Beratungen zu Abstandsregelungen bei Windenergie an Land. Berlin. Accessed December 17, 2019, from $<$ https://www.bmwi.de/Redaktion/DE/Publikationen/Studien/wissenschaftlichefundierung-der-beratungen-zu-abstandsregelungen-bei-windenergie-anland.pdf?_blob=publicationFile \&v $=4>$

Ott, R., Keil, S.I., 2017. Präferenzen der deutschen Bevölkerung zur Governance bei Windenergieanlagen. Energiewirtschaftliche Tagesfragen 67, 81-85. 
Rand, J., Hoen, B., 2017. Thirty years of North American wind energy acceptance research: What have we learned? Energy Res. Soc. Sci. 29, 135-148.

Stede, J., May, N., 2019. Strikte Mindestabstände bremsen den Ausbau der Windenergie (DIW Wochenbericht 48 / 2019).

Tröndle, T., Süsser, D., Lilliestam, J., 2019. Ohne Windenergie keine Energiewende (IASS Discussion Paper). Institute for Advanced Sustainability Studies. Accessed December 17, 2019, from <http://doi.org/10.2312/iass.2019.052>

Umweltbundesamt, 2019. Analyse der kurz- und mittelfristigen Verfügbarkeit von Flächen für die Windenergienutzung an Land (Climate Change No. 38/2019). Dessau-Roßlau. Accessed December 17, 2019, from $<$ https://www.umweltbundesamt.de/sites/default/files/medien/376/publikationen/clima te_change_38_2019_flaechenanalyse_windenergie_an_land.pdf $>$

Vuichard, P., Stauch, A., Dällenbach, N., 2019. Individual or collective? Community investment, local taxes, and the social acceptance of wind energy in Switzerland. Energy Res. Soc. Sci. 58, 101275.

Wegner, N., 2017. Abstände zwischen Windenergieanlagen und Siedlungsgebieten (Würzburger Berichte zum Umweltenergierecht No. 28). Accessed January 31, 2020, from $<$ https://stiftung-umweltenergierecht.de/wpcontent/uploads/2017/07/Stiftung_Umweltenergierecht_WueBerichte_28_Abstaende_Wi ndenergie.pdf $>$

Wolsink, M., 2012. Undesired reinforcement of harmful 'self-evident truths' concerning the implementation of wind power. Energy Policy 48, 83-87.

Wüstenhagen, R., Wolsink, M., Bürer, M.J., 2007. Social acceptance of renewable energy innovation: An introduction to the concept. Energy Policy 35, 2683-2691.

Zerrahn, A., 2017. Wind power and externalities. Ecol. Econ. 141, 245-260. 